\title{
Exploration of riffle-scale interactions between abiotic variables and microbial assemblages in the hyporheic zone
}

\author{
Lucie Sliva and D. Dudley Williams
}

\begin{abstract}
Molecular methods were applied to explore the composition of hyporheic bacterial assemblages and their possible interaction with interstitial physicochemical variables. Hyporheic flows on a riffle were manipulated (a downwelling zone was converted to an upwelling zone and vice versa) in order to examine the influence of vertical flow patterns on microbial assemblages. Bacterial assemblages were heterogeneously distributed throughout the riffle, the greatest similarity among them occurring at similar depths rather than in areas of similar flow regimes (upwelling versus downwelling). There was no correlation between the measured physicochemical variables and the microbial assemblages, with the exception of depth and sediment particle size. The flow manipulation in the original downwelling zone appeared to have had an effect on the microbial assemblages, although this influence may have been primarily due to a change in temperature in the manipulated region rather than an alteration of the vertical-flow direction per se.

Résumé : Des méthodes moléculaires nous ont servi à explorer la composition des peuplements hyporhéiques de bactéries et leurs interactions possibles avec les variables physicochimiques du milieu interstitiel. Nous avons manipulé l'écoulement hyporhéique dans une zone de rapides (une zone d'enfoncement des eaux a été transformée en zone de remontée et inversement) afin d'étudier l'influence des patterns d'écoulement vertical sur les peuplements microbiens. Les peuplements microbiens se répartissent de façon hétérogène dans la zone de rapides et les plus fortes similarités entre les peuplements s'observent aux profondeurs semblables plutôt que dans les zones à régime d'écoulement similaire (enfoncement ou remontée). Il n'y a pas de corrélation entre les peuplements microbiens et les variables physicochimiques mesurées, sauf la profondeur et la taille des particules du sédiment. La manipulation de l'écoulement dans la zone originale d'enfoncement de l'eau semble avoir eu un effet sur le peuplement microbien, bien que l'influence puisse peut-être s'expliquer plus par le changement de température dans la région manipulée que par le changement de l'écoulement vertical en lui-même.
\end{abstract}

[Traduit par la Rédaction]

\section{Introduction}

The hyporheic zone is subject to a unique and dynamic set of physicochemical conditions unlike those found in the more intensively studied surface- or ground-water habitats. Of particular interest are the two regions of contrasting hydraulic regimes within a single riffle, the downwelling and upwelling areas. The downwelling area generally occurs at the head of a riffle, where oxygen- and nutrient-rich surface water percolates downwards and is subject to larger daily and seasonal fluctuations in temperature, nutrient levels, and organic matter quality and quantity (Boulton et al. 1998). Downwelling of surface water in this area is caused by high local hydraulic pressure induced by current flow. The upwelling area is generally characterized by oxygen-poor groundwater moving through the alluvial sediment into the

Received 9 February 2004. Accepted 23 October 2004.

Published on the NRC Research Press Web site at

http://cjfas.nrc.ca on 12 March 2005.

J17961

L. Sliva and D.D. Williams. ${ }^{1}$ Department of Life Sciences, University of Toronto at Scarborough, 1265 Military Trail, Scarborough, ON M1C 1A4, Canada.

${ }^{1}$ Corresponding author (e-mail: williamsdd@utsc.utoronto.ca). stream, as well as surface water that has travelled the length of the riffle to reenter the stream. This area occurs at the downstream end of the riffle, where increasing stream depth produces a low-pressure zone, and is characterized by more constant temperature and nutrient and organic-matter levels. The contrasting hydrological and chemical characteristics of the downwelling area tend to be more conducive to aerobic processes such as respiration, nitrification, and methane or sulphide oxidation, whereas those of the upwelling area are more conducive to anaerobic processes such as denitrification, ammonification, and sulphate reduction (Hendricks 1993).

Within the hyporheic zone, microbes are thought to account for the bulk of the living biomass, which in most hyporheic ecosystems is dominated by heterotrophic bacteria (Findlay and Sobczak 2000). Despite this, microbial patterns and processes within the hyporheic zone are poorly known compared with those in other aquatic habitats (Findlay and Sobczak 2000). In the few existing studies, researchers have observed higher bacterial abundances, activity, and bacterial respiration in downwelling zones and shallow sediments than in upwelling zones and deeper sediments (e.g., Findlay and Sobczak 1996; Hendricks 1996). Henry and Fischer (2003), for example, have found the downwelling zones of sandbar edges in an Arizona creek to contain communities 
Fig. 1. (a) Location of the study area, northeast of Guelph, Ontario $\left(43^{\circ} 43^{\prime} \mathrm{N}, 80^{\circ} 16^{\prime} \mathrm{W}\right)$. (b) Distribution of the pre-manipulation sample-collection sites. (c) Distribution of the manipulation and post-manipulation sample-collection sites (C, control treatment; M, manipulation treatment; S1, originally downwelling zone; S2, originally upwelling zone).

(a)

(b)
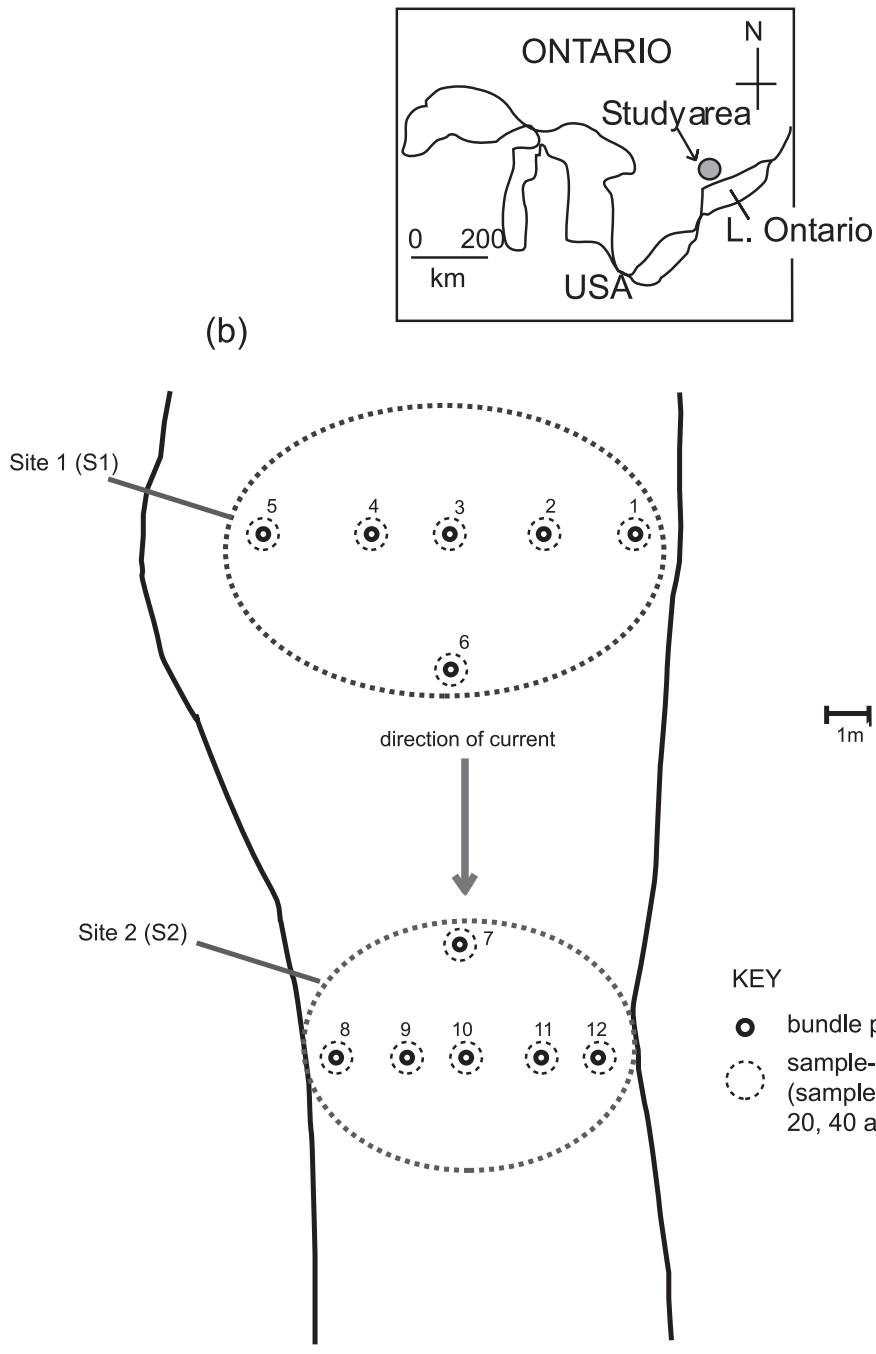

KEY

(c)

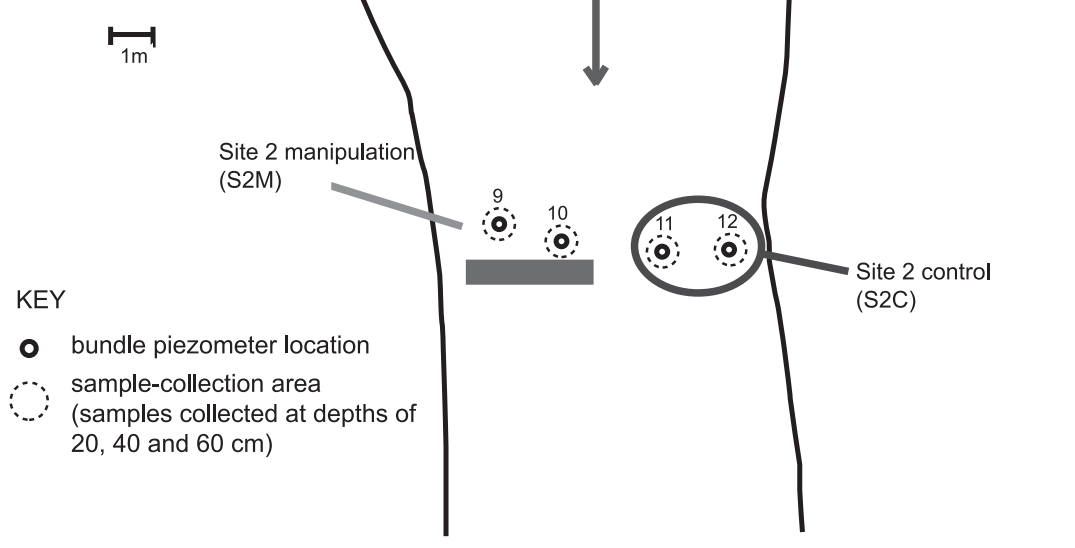

with abundant nitrogen-fixing cyanobacteria, while nonnitrogen-fixing taxa were predominant at the upwelling edges. However, other studies have reported no variations in these parameters between the two zones (Claret et al. 1998; Franken et al. 2001). Besides hydrology, physical characteristics of subsurface sediments, such as sediment surface area, have also been noted to influence bacteria (Leichtfried 1985).

Despite the importance of manipulative studies to testing and establishing the role of physicochemistry in determining the diversity and structure of hyporheic biological assemblages, very few field-scale manipulative studies exist (i.e., Richards and Bacon 1994; Boulton and Foster 1998). To our knowledge none has attempted to use field manipulations to look at the influence of physicochemistry in structuring the microbial assemblages in the hyporheic zone.

The objectives of this study were $(i)$ to explore the composition of hyporheic bacterial assemblages; (ii) to examine associations between interstitial physicochemical variables and microbial assemblages; and (iii) to test the strength of influence of a suspected major variable (hyporheic flow) on microbial assemblages by experimentally reversing upwelling and downwelling areas in a riffle.

\section{Methods}

\section{Study site}

The study site was a pool-riffle-pool segment of the Speed River northeast of the city of Guelph, Ontario $\left(43^{\circ} 43^{\prime} \mathrm{N}, 80^{\circ} 16^{\prime} \mathrm{W}\right)$, situated about $5 \mathrm{~km}$ from the spring source (Fig. 1a). The local geography is composed of undulating hills, glacial spillways, and swampy depressions with the river flowing through an average gradient of $2 \mathrm{~m} \cdot \mathrm{km}^{-1}$ (Chapman and Putnam 1966). The river is $4-6 \mathrm{~m}$ wide at the site and varies in depth between around 0.15 and $0.35 \mathrm{~m}$. The Speed River is characterized by peak flow during the spring snowmelt and reduced flow during the rest of the year. The summer base-flow discharge is about $0.1 \mathrm{~m}^{3} \cdot \mathrm{s}^{-1}$, and in the winter this discharge increases by a factor of 2-3. To a depth of about $30 \mathrm{~cm}$, the substrate is primarily composed of gravel intermixed with silt, sand, and a few larger 
Fig. 2. Experimental flow-manipulation setup. (a) S1M is the upstream manipulation area, where a downwelling zone was converted to upwelling. (b) S2M is the downwelling manipulation area, where an upwelling zone was converted to downwelling. The scale is not accurate.

(a)

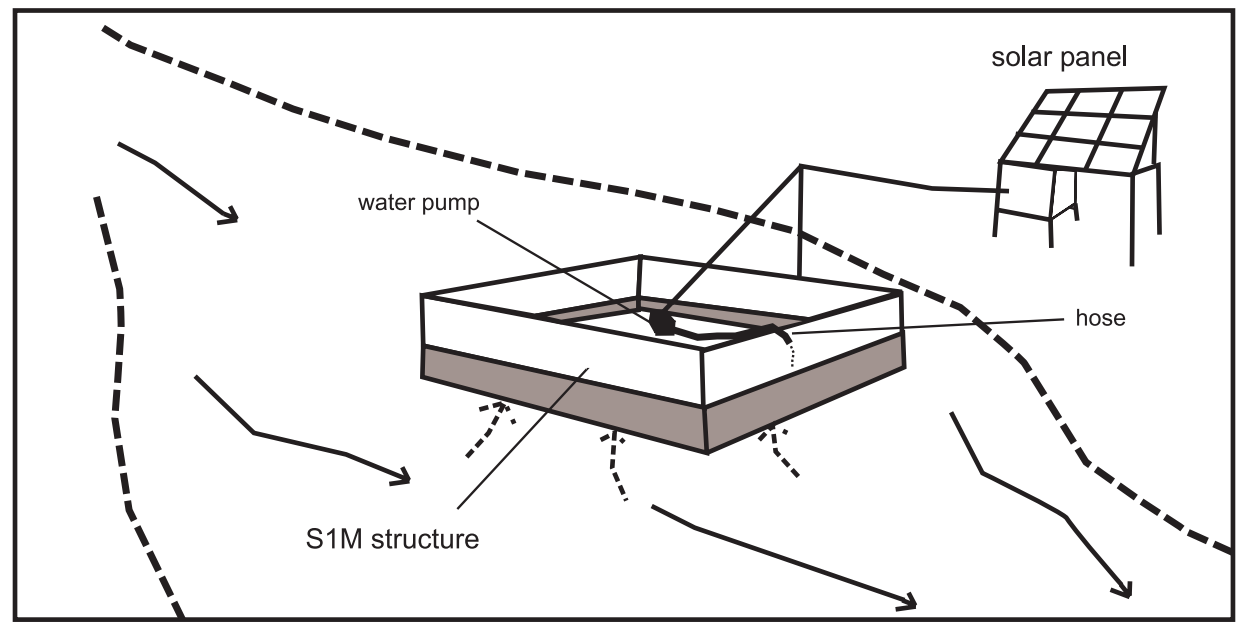

KEY

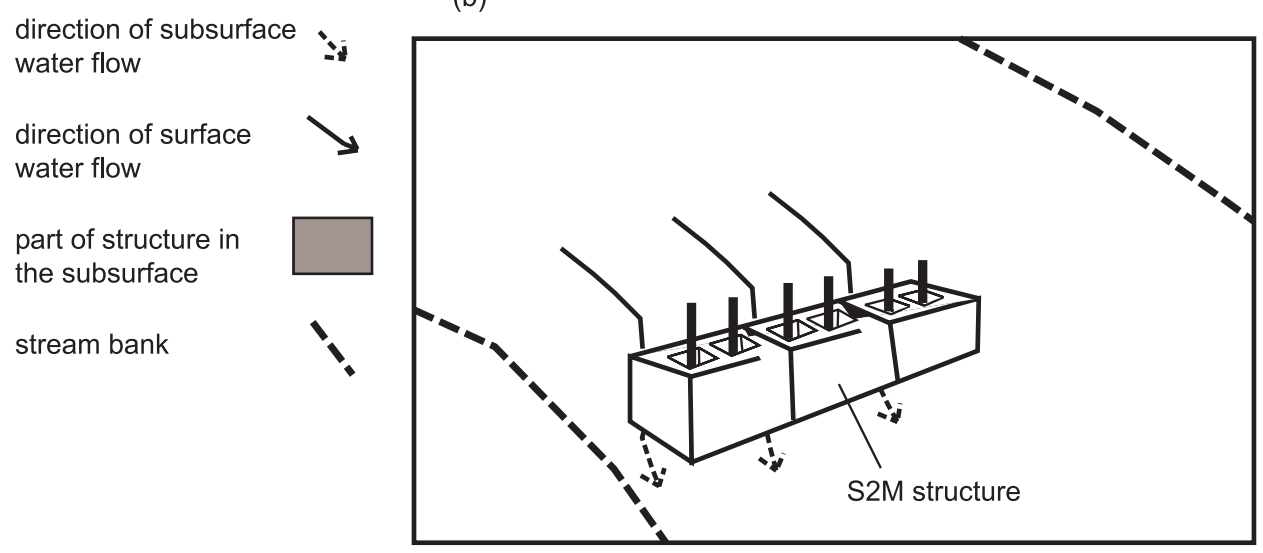

dolomite slabs. Below this, the substrate is of low heterogeneity and is dominated by medium and fine sands. The vegetation on the north bank of the river is composed of eastern white-cedar (Thuja occidentalis L.), whereas that on the south bank consists primarily of open fields with pockets of deciduous trees.

\section{Flow manipulations}

The flow-manipulation portion of this study involved the alteration of a portion of the riffle upwelling area into a downwelling area and vice versa. The upwelling and downwelling areas were about $11 \mathrm{~m}$ apart (Fig. $1 b$ ). The redirection of subsurface flows in the initially downwelling area (head of the riffle) consisted of isolating a $6.25-\mathrm{m}^{2}$ area with an open (top and bottom), galvanized-sheet-metal, waterproof structure (having 1-m high walls), similar in function to a caisson used to provide a working space for construction projects below ground or under water (Fig. 1c). This structure was buried $40 \mathrm{~cm}$ in the streambed. Water was pumped continuously out of the caisson with a submersible water pump powered by a photovoltaic system, at a rate that maintained a water surface within the structure that was lower than that of the outside stream (S1M structure; Figs. $1 c$ and $2 a$ ). The extent of this flow reversal was measured by two sets of mini piezometers installed at three depths $(20,40$, and $60 \mathrm{~cm})$ within the structure. The distance between the replicate piezometer sites was $1.5 \mathrm{~m}$. The redirection of subsurface flows in the initially upwelling area (downstream end of the riffle) involved constructing a cement-block barrier secured by metal poles that spanned half the width of the river (S2M structure; Figs. $1 c$ and $2 b$ ). This was expected to increase the hyporheic hydraulic head upstream of the structure and lower the hydraulic head downstream of the structure, which caused surface water to infiltrate down into the sediments, thus producing a local downwelling zone similar to natural downwellings produced by logs positioned perpendicular to current (Baxter and Hauer 2000). Since the number of samples that could be collected was limited by the size of the area that was practicable to manipulate, the replication of samples was limited to two sets of samples per depth (each sample set corresponds to sediments collected at 20,40, and $60 \mathrm{~cm}$ ) within the ma- 
nipulated areas. Two sets of control samples were also collected at each of these depths within the upstream and downstream areas that were not manipulated (Fig. 1c). This resulted in 6 samples in each of the two manipulated and control areas and a total of 24 samples collected during the manipulation period. The distance between the upstream manipulation (S1M) structure and downstream control (S2C) area was $8 \mathrm{~m}$. The distance between the S1M area and upstream control (S1C) area was $2 \mathrm{~m}$. The distance between the downstream control and manipulation areas was the same. The manipulation continued for 1 month, as the recovery of the invertebrate community was also studied (unpublished), and it takes about 1 month for hyporheic invertebrate communities at this site to recover after disturbance (Williams and Hynes 1976).

\section{Sample collection and physicochemical analyses}

The area was sampled three times during the summer and autumn of 2001. The pre-flow-manipulation samples were collected during the second week of July. The flowmanipulation samples were collected during the first week of October after the hyporheic flows had been reversed for 1 month. The post-flow-manipulation samples were collected during the first week of November, 1 month after the manipulation structures had been removed and the system returned to pre-manipulation status.

Hyporheic sediment samples were collected 20, 40, and $60 \mathrm{~cm}$ below the surface of the riverbed with a standpipe corer ( $n=12$ at each depth for the pre-manipulation set and $n=10$ at each depth for the manipulation and postmanipulation sets; see Fig. 1 for sampling locations). This corer collects $25 \mathrm{~cm}^{3}$ of sediment per sample (Williams and Hynes 1974). The samples were collected within $30 \mathrm{~cm}$ of corresponding piezometers that were used to measure hydraulic heads and to collect water samples for chemical analysis. The sediment samples used for microbial analysis were washed out of the standpipe corer chamber with sterile, filtered water into sterile plastic bags, homogenized by thorough mixing, and transported to the laboratory on ice. Immediately upon return to the laboratory, $10 \mathrm{~g}$ of the sediment was removed from each sample for microbial analysis and stored at $-80{ }^{\circ} \mathrm{C}$.

The hydraulic heads were measured on site with an electronic water-level indicator. The vertical hydraulic gradient (VHG) was determined by direct determination of the piezometric head relative to the stream surface, which provided an estimate of the potential strength of the hydrological exchange occurring within the upwelling and downwelling zones (Boulton et al. 1998). VHG was determined by the following equation: $\mathrm{VHG}=\mathrm{d} h / \mathrm{d} l$, where $\mathrm{d} h$ is the difference in head between the water surface in the piezometer and the level of the stream surface (hydraulic-head differential, in centimetres), and $\mathrm{d} l$ is the depth from the substrate surface to the first opening in the piezometer's side wall (Baxter and Hauer 2000). VHG is a unitless measure that is positive under upwelling conditions and negative under downwelling conditions.

Water samples at depths of 20,40, and $60 \mathrm{~cm}$ were withdrawn from each piezometer with a peristaltic pump and Tygon $^{\mathrm{TM}} \mathrm{R} 3603$ tubing. Water standing in the piezometers was discarded, after which a $250-\mathrm{mL}$ sample was taken for on-site analysis of temperature, dissolved oxygen (DO), redox, conductivity, and $\mathrm{pH}$, using a Hydrolab Scout $\mathrm{H}_{2} \mathrm{O}$ multiprobe (Hach Co., Loveland, Colorado). Another set of 250-mL samples was taken from the piezometers, stored on ice, and transported to the laboratory, where they were immediately filtered (Gelman A/E/ 1.0- $\mu \mathrm{m}$ glass-fiber filters) and analysed for $\mathrm{NO}_{3}-\mathrm{N}$ and $\mathrm{NH}_{4}-\mathrm{N}$, using a Hach ${ }^{\mathrm{TM}}$ DR2000 spectrophotometer (Hach Co.), within $24 \mathrm{~h}$ of collection. Water samples to be used for dissolved organic carbon (DOC) analysis were filtered with Gelman A/E/ $0.45-\mu \mathrm{m}$ glass-fiber filters, acidified to $\mathrm{pH} 3.0$ with sulphuric acid, and analysed at Environmental Engineering, Department of Civil Engineering, University of Toronto, Toronto, Ontario. Glassware and sample bottles were acid-washed in 1:6 $\mathrm{HNO}_{3}$ and rinsed six times in distilled water and five times in Nanopure ${ }^{\mathrm{TM}}$ deionized water. Particulate organic matter (POM) in each sediment sample was quantified by the loss of weight on ignition method (Nelson and Sommers 1996) after removing hyporheic fauna. The sediment samples were first oven-dried at $105{ }^{\circ} \mathrm{C}$ for $24 \mathrm{~h}$. Dried samples were weighed, ashed at $400{ }^{\circ} \mathrm{C}$ for $14 \mathrm{~h}$, and weighed again. The amount of organic matter in the core sample per unit weight of sediment was determined by dividing the loss of weight on ignition by the weight of the core sample.

\section{Microbial analysis}

Two methods were used to extract microbial DNA directly from the hyporheic sediments. The first was with the Ultra Clean Soil Kit (Mo Bio Laboratories Inc., Carlsbad, California), which was used to extract DNA from the premanipulation and manipulation samples. It was later determined that although the DNA extracted with this method was very clean, not requiring any further purification steps, it provided a poor yield compared with a subsequently modified (Zhou et al. 1996) method, which was applied to the postmanipulation set of samples.

Extracted DNA was amplified using universal bacterial primers 63F (5'-CAGGCCTAACACATGCAAGTC-3') and 1389R ( $5^{\prime}$-ACGGGCGGTGTGTACAAG-3') (Osborn et al. 2000), which were labelled at the $5^{\prime}$ end with the phosphoramidite dyes 6-FAM and HEX (Sigma-Genosys, Oakville, Ontario), respectively. All reagents were prepared as a master mix before the addition of the template DNA. One nanogram of template DNA was amplified in a $50-\mu \mathrm{L}$ reaction consisting of $5 \mu \mathrm{L}$ of $10 \times$ polymerase chain reaction (PCR) buffer, $2 \mathrm{U}$ of Biotools DNA polymerase $\left(1 \mathrm{U} \cdot \mu \mathrm{L}^{-1}\right.$, BandM Labs, Madrid, Spain), $0.8 \mu \mathrm{mol} \cdot \mathrm{L}^{-1}$ each primer, $0.2 \mathrm{mmol} \cdot \mathrm{L}^{-1} \mathrm{dNTP} \operatorname{mix}(\mathrm{dATP}, \mathrm{dCTP}, \mathrm{dGTP}$, dTTP; Roche Diagnostics Corp., Indianapolis, Indiana), $3 \mathrm{mmol} \cdot \mathrm{L}^{-1}$ $\mathrm{MgCl}$, and $5 \mu \mathrm{L}$ of MasterAmp ${ }^{\mathrm{TM}} 10 \times$ PCR enhancer. The cycling conditions consisted of initial denaturing at $94{ }^{\circ} \mathrm{C}$ for $2 \mathrm{~min}$, followed by 30 cycles of $94^{\circ} \mathrm{C}$ for $1 \mathrm{~min}, 57^{\circ} \mathrm{C}$ for $1 \mathrm{~min}$ and $72{ }^{\circ} \mathrm{C}$ for $2 \mathrm{~min}$. This was followed by a final extension step of $72{ }^{\circ} \mathrm{C}$ for $10 \mathrm{~min}$.

Terminal restriction fragment length polymorphism (T-RFLP) analysis was used to assess the degree of microbialassemblage similarity, and is based on digestion by restriction endonuclease of fluorescently end-labelled PCR products. The restriction endonuclease used in this study 
was MspI (New England Biolabs Inc., Beverly, Massachusetts). For the $M s p$ I restriction digestion reactions, $5 \mu \mathrm{L}$ of buffer, $1 \mu \mathrm{L}(20 \mathrm{U})$ of restriction enzyme, $20 \mu \mathrm{L}$ of PCR product, and $24 \mu \mathrm{L}$ of sterile distilled $\mathrm{H}_{2} \mathrm{O}$ were combined. The mixture was incubated at $37{ }^{\circ} \mathrm{C}$ for $4 \mathrm{~h}$. Ten microlitres of the digested DNA was run on $3 \%$ agarose gel stained with ethidium bromide to check if the products were fully digested. Digestion was deemed complete because (i) 1500base-pair (bp) fragments were never seen; ( $i i)$ incomplete digestion is normally encountered only when there is excess DNA in the reaction, which was never the case with our samples; and (iii) good result replication suggests that digestion was complete. Further, the primers have been tested in many other studies, and annealing to any gene section other than $16 \mathrm{~S}$ (e.g., 18S) is not observed when the correct PCR protocol is applied. The remainder of the digested DNA was sent to the Molecular Supercentre, University of Guelph, Ontario, where the digested products were mixed with a DNA size standard (size range between 30 and 600 bp), itself labelled with a distinct dye, and the DNA fragments were analysed on an ABI 377 automatic sequencer (Applied Biosystems Inc., Fredmont, California).

A clustering algorithm was used to align the terminal restriction fragment profiles, which corresponded to specific microbial taxa or operational taxonomic units (OTU). This was done using GeneScan ${ }^{\circledR}$ software (version 2.1; Applied Biosystems Inc. 2000) and by setting the error that determines the fragment size to some predetermined value. Bacterial taxa will be referred to as OTUs throughout this paper, since each fragment does not necessarily correspond to a specific phylogenetic level, although it does roughly correlate with the level of genus. In this study, the error was set to $\pm 1.0 \mathrm{bp}$, and thus OTUs that differed by less than $1.0 \mathrm{bp}$ were considered identical and clustered together. All fragments within such a defined cluster were then assigned the average value of the sizes within the cluster. The minimum peak detection threshold value was set to 100 fluorescence units. Peaks not present in the pre-manipulation samples were removed from the flow-manipulation sample set, so that portions of the two assemblages compared were kept the same.

T-RFLP is based solely on fragment size, and direct comparison with a sequence database such as the Ribosomal Database Project II (RDP II, version 8.0, University of Michigan) is possible (Marsh et al. 2000). The T-RFLP analysis program of the database was used to perform an in silico digestion (all bacterial sequences in the database were used in a model digestion) with MspI of all the RDP sequences amplifiable by the $63 \mathrm{~F}$ primer. The results of this analysis were compared with the terminal-fragment sizes obtained from MspI digestion of the hyporheic assemblage DNA.

\section{Data analysis}

Summary statistics, correlations, analysis of variance (ANOVA), and nonparametric analyses were performed with StatView ${ }^{\circledR}$ for Windows, version 5.0 (SAS Institute Inc. 1999). Microbial data were $\log (x+1)$ transformed where this improved normality. Physicochemical variables were log $(x+1)$ transformed to improve normality and standardized to zero mean and unit variance (Jongman et al. 1995). When differences in physicochemical and biological variables among depths were analysed, samples belonging to the same zone (upwelling versus downwelling) were grouped to increase the number of replicates at each depth. Similarly, samples from similar depths were grouped when differences between zones were analysed to increase the number of replicates in each zone. Principal components analysis was used to preselect physicochemical variables of importance for further analysis in order to decrease the number of variables to be used and to reduce intercorrelations. Where multiple tests were performed (e.g., testing for differences among physicochemical variable for different depths and zones), Bonferroni correction was applied in order to avoid spurious positives. Multivariate statistical analyses were performed using Canoco ${ }^{\circledR}$ for Windows, version 4.0 (Centre for Biometry 1997). Detrended correspondence analysis was used to determine which multivariate, linear (regularized discriminant analysis), or unimodal (canonical correspondence analysis (CCA)) method to apply to the data sets (Jongman et al. 1995). Since all biological data displayed unimodal distributions (first gradient of detrended correspondence analysis >3), CCA was used to analyse patterns in relationships between the physicochemical and biological parameters. CCA looks for coefficients of environmental variables to obtain a site score that maximizes the variance of average position of species. It is a direct gradient analysis technique that constrains the extracted pattern of microbial assemblages to a linear combination of the measured environmental variables, and it is a proven, robust method for describing species-environment relationships (for a complete review see Palmer 1993). Unconstrained correspondence analysis (CA) was applied to the species data first to determine significant patterns in the assemblage before the analysis was constrained by environmental data (CCA).

\section{Results}

\section{Physicochemical patterns}

The decrease in hyporheic exchange from pre-manipulation to post-manipulation sampling periods could be observed as an overall increase in vertical hydraulic gradient and a decrease in DO, which signify an increased upward flow of groundwater towards the stream and a decreased contribution of stream water to hyporheic flows (Table 1). Notably, there was a large decrease in water temperature over the three sampling periods, which can be attributed to natural seasonal differences.

Before the manipulation, significant differences in temperature, ammonium, VHG, and conductivity between the S1 (downwelling) and S2 (upwelling) areas were seen (Table 1), values being lower in S1 than in S2. The observed pattern of temperature difference between $\mathrm{S} 1$ and $\mathrm{S} 2$ was opposite to what was expected, since at that time of the year, the groundwater was colder than surface water. This could be explained by diurnal stream temperature change occurring more rapidly than on-site chemistry analysis for that sampling period; S1 samples were analysed first, making them appear, on average, cooler than the shallow hyporheic samples sampled in S2. Smaller sample size as well as later sampling time during the day avoided this problem during subsequent sampling periods. Significant differences in 
Table 1. Comparison of average values (+1 standard deviation, in parentheses) of physicochemical variables among zones for each sampling period as determined by analysis of variance.

\begin{tabular}{|c|c|c|c|c|c|c|}
\hline & VHG & $\begin{array}{l}\text { DO } \\
\left(\mathrm{mg} \cdot \mathrm{L}^{-1}\right)\end{array}$ & $\begin{array}{l}\text { Temperature } \\
\left({ }^{\circ} \mathrm{C}\right)\end{array}$ & $\mathrm{pH}$ & $\begin{array}{l}\text { Conductivity } \\
\left(\mathrm{S} \cdot \mathrm{cm}^{-1}\right)\end{array}$ & $\begin{array}{l}\mathrm{NH}_{4} \\
\left(\mathrm{mg} \cdot \mathrm{L}^{-1}\right)\end{array}$ \\
\hline \multicolumn{7}{|c|}{ Before manipulation } \\
\hline S1 & $0.004(0.017)$ & $5.09(2.4)$ & $17.3(0.1)$ & $7.5(0.4)$ & $0.493(0.017)$ & $0.008(0.006)$ \\
\hline S2 & $0.021(0.015)$ & $2.74(1.04)$ & $18.3(0.5)$ & $7.3(0.1)$ & $0.529(0.036)$ & $0.037(0.035)$ \\
\hline$n$ & 16 & 18 & 18 & 18 & 18 & 18 \\
\hline$F$ & 8.291 & & 12.03 & & 7.368 & 9.107 \\
\hline \multicolumn{7}{|c|}{ Manipulation } \\
\hline S1C & $0.003(0.015)$ & $3.84(2.66)$ & $13.1(0.4)$ & $7.7(0.21)$ & $0.521(0.006)$ & $0.142(0.115)$ \\
\hline S2M & $0.024(0.028)$ & $2.37(1.62)$ & $11.6(0.5)$ & $7.5(0.09)$ & $0.532(0.007)$ & $0.187(0.050)$ \\
\hline $\mathrm{S} 2 \mathrm{C}$ & $0.02(0.005)$ & $2.37(0.22)$ & $12.3(0.4)$ & $7.4(0.02)$ & $0.515(0.003)$ & $0.14(0.100)$ \\
\hline$n$ & 12 & 12 & 12 & 12 & 12 & 12 \\
\hline $\mathrm{S} 1$ & $0.050(0.02)$ & $2.9(0.9)$ & $7.0(0.6)$ & $7.2(0.1)$ & $0.498(0.039)$ & $0.160(0.07)$ \\
\hline $\mathrm{S} 2$ & $0.080(0.06)$ & $2.8(0.74)$ & $6.6(0.8)$ & $7.4(0.1)$ & $0.491(0.009)$ & $0.160(0.06)$ \\
\hline$n$ & 18 & 18 & 18 & 18 & 18 & 18 \\
\hline$F$ & & & & 12.14 & & \\
\hline$p$ & ns & ns & $\mathrm{ns}$ & 0.002 & ns & $\mathrm{ns}$ \\
\hline
\end{tabular}

Note: Depths $(20,40$, and $60 \mathrm{~cm})$ were combined to increase the sample size. S1M, upstream manipulation area (with control area S1C); S2M, downstream manipulation area (with control area S2C); VHG, vertical hydraulic gradient; DO, dissolved oxygen; ns, not significant.

Table 2. Comparison of average values ( +1 standard deviation, in parentheses) of physicochemical variables (three particle sizes, DO, and temperature) at three depths below the river bed for each sampling period.

\begin{tabular}{|c|c|c|c|c|c|}
\hline \multirow[b]{2}{*}{ Depth $(\mathrm{cm})$} & \multicolumn{3}{|c|}{ Sediment particle size } & \multirow[b]{2}{*}{$\mathrm{DO}\left(\mathrm{mg} \cdot \mathrm{L}^{-1}\right)$} & \multirow[b]{2}{*}{ Temperature $\left({ }^{\circ} \mathrm{C}\right)$} \\
\hline & $>2 \mathrm{~mm}(\%)$ & $<600 \mu \mathrm{m}(\%)$ & $<250 \mu \mathrm{m}(\%)$ & & \\
\hline \multicolumn{6}{|c|}{ Before manipulation } \\
\hline 40 & $24(6)$ & $47(9)$ & $21(5)$ & $3.51(2.06)$ & $17.8(0.8)$ \\
\hline 60 & $19(9)$ & $56(12)$ & $56(13)$ & 3.35 (1.99) & $17.6(0.9)$ \\
\hline$n$ & 12 & 12 & 12 & 12 & 12 \\
\hline \multicolumn{6}{|c|}{ Manipulation } \\
\hline 20 & $27(6)$ & $36(8)$ & $12(3)$ & $4.03(2.40)$ & $12.8(1.7)$ \\
\hline 40 & $29(5)$ & $39(5)$ & $17(4)$ & $2.16(0.50)$ & $13(1.2)$ \\
\hline 60 & $24(8)$ & $42(10)$ & $18(6)$ & $1.97(0.52)$ & $13(0.8)$ \\
\hline$n$ & 6 & 6 & 6 & 6 & 6 \\
\hline 20 & $27(4)$ & $35(6)$ & $14(3)$ & $3.85(1.32)$ & $6.2(0.4)$ \\
\hline 40 & $28(6)$ & $39(6)$ & $18(4)$ & $2.88(0.67)$ & $6.8(0.5)$ \\
\hline 60 & $29(4)$ & $40(5)$ & $19(3)$ & $2.48(0.30)$ & $7.4(0.7)$ \\
\hline$n$ & 12 & 12 & 12 & 12 & 12 \\
\hline$F$ & & 7.333 & 4.694 & 45.6 & 5.82 \\
\hline$p$ & $\mathrm{~ns}$ & 0.003 & 0.01 & $<0.001$ & 0.008 \\
\hline
\end{tabular}

Note: Only values that differed significantly among depths, as determined by analysis of variance, are shown. Sites were combined to increase sample size. DO, dissolved oxygen; ns, not significant. 
means among depths occurred for the sediment size fraction $<600 \mu \mathrm{m}$, which decreased with depth (Table 2).

During the flow-manipulation period, significant differences in VHG, $\mathrm{pH}$, and temperature were found between the control areas of the two sites (Table 1). Significant differences in VHG, temperature, and $\mathrm{pH}$ were also found between the $\mathrm{S} 1$ control and manipulation areas. The S1 control area (S1C) was generally downwelling, with lower VHG and temperature and higher $\mathrm{pH}$. In $\mathrm{S} 2$, the control area $(\mathrm{S} 2 \mathrm{C})$ had a significantly lower $\mathrm{pH}$ and higher temperature and conductivity than the manipulated area (S2M). The only significant differences among depths during this sampling period were observed for DO, which decreased with depth, and sediment size fraction $<250 \mu \mathrm{m}$, which increased with depth (Table 2).

During the post-manipulation sampling period, the only significant physicochemical difference between the sites was in temperature, which was higher in S1 (Table 1). The VHG values showed strong upwelling at both sites, and the difference in VHG between the upstream and downstream sites was not significant. Significant differences in physicochemical values among depths were observed for temperature, DO, and sediment size fractions $<250$ and $<600 \mu \mathrm{m}$ (Table 2). Temperature increased with depth, which corresponded to cooler surface water than groundwater at this time of year. The proportion of the small sediment fractions increased with depth below the streambed.

\section{Microorganisms}

The total numbers of OTUs used in further analyses of the pre-manipulation, manipulation, and post-manipulation data sets were 73, 70, and 95, respectively. Fewer than $50 \%$ of the OTUs in all sampling periods had corresponding fragment sizes derived from the model restriction digests of RDP II sequenced bacteria. Most of the hyporheic OTUs also present in the model digestion were associated with aerobic phylotypes. Many of the OTUs were associated with more than one phylotype. All phylotypes were gramnegative and belonged to the following three groups: Cytophaga, alpha-Proteobacteria, and gamma-Proteobacteria. Although taxa belonging to the subgroup Cytophaga appeared in both the pre-manipulation and manipulation sample sets, none was present in the post-manipulation samples. The OTUs that had the largest abundance values, as measured by fluorescence intensity, and their associated RDP phylotypes are shown in Table 3.

The results of an unweighted pair group method using arithmetic averages (UPGMA) cluster analysis are shown in Fig. 3. The pre-manipulation samples did not include five of the $60 \mathrm{~cm}$ depth samples and three of the $40 \mathrm{~cm}$ depth samples, since not enough amplifiable DNA could be extracted from them with the technique used at the time. Moreover, a low quantity of extractable DNA from deeper sediments was common to all of the samples analysed. The assemblages varied from being less than $20 \%$ to more than $90 \%$ similar, as measured by Pearson's correlation coefficient. There was an overall tendency for some samples from similar depths to cluster together for all three sampling periods. There was no clustering of samples originating from the same site or treatment during the manipulation.
Microbial richness, as measured by total number of OTUs per site, was compared among sites, depths, and treatments. No significant differences occurred except after the manipulation, when richness was greater in S2 than in S1 (MannWhitney test, $n=12, p=0.01$ ). No correlation was found between bacterial OTU richness and physicochemical variables before and after the manipulation. During the manipulation, OTU richness was positively correlated with temperature and VHG (Spearman's rank correlation, $r=$ 0.519 and $0.573, p=0.0127$ and 0.006 , respectively).

Although CCA of the log-transformed microbial data and the standardized physicochemical data showed that all CCA axes were able to account for a relatively large proportion of variation in the microbial data $(45 \%-58 \%$; Table 4$)$, none of this was significant as tested by a Monte Carlo permutation test. Analysis of the pre-manipulation microbial data showed that the first species axis was a gradient of sediment size fractions $<250 \mu \mathrm{m}$ and $>2 \mathrm{~mm}$ and POM ( $r=0.82,-0.47$, and -0.41 , respectively), and the second axis a gradient of temperature and DO $(r=0.31$ and 0.56 , respectively; Fig. $4 a$ ). No clear separation of sites or depths was observed along either of the first two axes. There were several OTUs associated with increasing DOC (e.g., 395, 135, 274, and 449 bp); however, only one could be identified (104 bp belonging to gamma-Proteobacteria) on the RDP database. All the CCA axes could explain $45 \%$ of the variation in microbial-assemblage data (Table 4). Depth was not as well represented in this analysis because very few $60 \mathrm{~cm}$ depth samples could be included.

For the flow-manipulation data, CCA analysis showed that the first species axis, gradient of depth, $\mathrm{pH}$, and DO $(r=$ $-0.64,0.53$, and 0.49 , respectively), was the most important in determining variability in microbial assemblages (Fig. 4b). The second axis was a slight gradient of VHG and temperature $(r=-0.36$ and -0.34 , respectively). There was a slight separation of deeper and shallower samples along the first axis, with shallower samples associating with increased gradient of DO, pH, and DOC. Most OTUs were also associated with the increased values of these environmental variables. Fewer OTUs were associated with the second axis. CCA of this sample set could explain about $54 \%$ of the species gradient as determined by CA.

The post-manipulation microbial data were influenced by a gradient of sediment size fraction $<250 \mu \mathrm{m}$, temperature, and $\mathrm{pH}$ along the first axis $(r=0.61,0.46$, and -0.52 , respectively; Fig. 4c). The second axis was primarily a gradient of depth $(r=-0.76)$. Once again, there was a slight separation of samples from different depths, this time along the second axis. Most of the OTUs were also spread out along this gradient of depth. CCA of the post-manipulation microbial assemblages could explain about $58 \%$ of the species gradient as determined by CA.

\section{Discussion}

\section{The Speed River physicochemical environment}

The dominance of hyporheic exchange across the riffle scale was gradually reduced over the sampling periods, being most distinct before the manipulation and disappearing completely after the manipulation. This agrees with previous studies of this section of the Speed River, which have shown 
Table 3. Most-abundant operational taxonomic units and their corresponding ribosomal database (RDP) phylotypes before the manipulation, during the manipulation, and after the manipulation.

\begin{tabular}{|c|c|c|}
\hline Fragment length (bp) & RDP phylotypes & RDP group \\
\hline \multicolumn{3}{|l|}{ Before manipulation } \\
\hline 402 & Sulphitobacter, Rhodobacter, Paracoccus, Roseobacter & Alpha- and beta-Proteobacteria \\
\hline 404 & $\begin{array}{l}\text { Paracoccus, Rhodovulum, Hyphomicrobium, Roseobacter, } \\
\text { Rhodospirillum, Magnetospirillum, Sulfitobacter }\end{array}$ & Alpha-Proteobacteria \\
\hline 405 & Hyphomicrobium, Paracoccus & Alpha-Proteobacteria \\
\hline 406 & Rhodospirillum, Rhodovibrio & Alpha-Proteobacteria \\
\hline 457 & Pseudomonas, Pantoea, Cytophaga & Gamma-Proteobacteria, Cytophaga \\
\hline 475 & Thiomicrospira & Gamma-Proteobacteria \\
\hline 476 & Vibrio & Gamma-Proteobacteria \\
\hline \multicolumn{3}{|l|}{ During manipulation } \\
\hline 111 & na & \\
\hline 456 & Pseudomonas, Pseudoalteromonas, Pantoea & Gamma-Proteobacteria \\
\hline \multicolumn{3}{|l|}{ After manipulation } \\
\hline 113 & Unnamed strain & Alpha-Proteobacteria \\
\hline 114 & Rhodocista, Methylosinus, Asticaccaulis, Pseudomonas & Alpha-Proteobacteria \\
\hline 115 & $\begin{array}{l}\text { Caulobacter, Methylocystis, Methylosinus, Pedomicrobium, } \\
\text { Brevundimonas, Azospirillum }\end{array}$ & Alpha-Proteobacteria \\
\hline 116 & Caulobacter, Azospirillum, Rhodothalasium & Alpha-Proteobacteria \\
\hline 118 & Rhodovibrio & Alpha-Proteobacteria \\
\hline 126 & Rhodobium, Rhodopseudomonas & Alpha-Proteobacteria \\
\hline 127 & A couple of unnamed clones & Alpha and beta Proteobacteria \\
\hline 471 & Vibrio, Photobacterium, Shewanella, Listonella & Gamma-Proteobacteria \\
\hline 487 & Salinivibrio & Gamma-Proteobacteria \\
\hline
\end{tabular}

Note: na, not available; bp, base pairs.

that true hyporheic exchange, and the associated chemical differentiation between upwelling (S2) and downwelling (S1) areas, occur mainly during the summer, when the flows are lowest (Storey et al. 2003).

The pre-manipulation physicochemical results show that S1 (the downwelling zone) had characteristics more typical of the stream surface water, characterized by lower conductivity and ammonium, which infiltrated the subsurface at the head of the riffle. Speed River surface water is characterized by higher nitrogen and DOC and lower ammonium values than interstitial water (R. Storey, Department of Life Sciences, University of Toronto at Scarborough, 1265 Military Trail, Scarborough, ON M1C 1A4, unpublished data).

During the manipulation, there still was a differentiation in the direction of vertical flow and chemistry between the control areas, S1C having higher $\mathrm{pH}$ and temperature and lower VHG than S2C. Higher $\mathrm{pH}$ values in the downwelling area provide evidence for the presence of recently infiltrated surface water, which tends to be more alkaline than that in the hyporheic zone. As this water moves through the subsurface, $\mathrm{pH}$ decreases because it is linked to increasing $\mathrm{CO}_{2}$ content produced by respiration along the flow line (Williams 1984). There was evidence of physicochemical differences between the control and manipulated areas. S1M had higher VHG and temperature and lower $\mathrm{pH}$ than S1C. This supports the success of flow reversal from downwelling to upwelling in S1M. The increase in temperature in S1M was an unintentional, and difficult to avoid, side effect of the manipulation structure itself. It was observed during the manipulation period that the slower moving water in the structure tended to be $3-4{ }^{\circ} \mathrm{C}$ higher than the river surface water.

There was also some evidence for altered flows in S2 (originally an upwelling zone). Although there was no significant difference between the VHG values of the control 


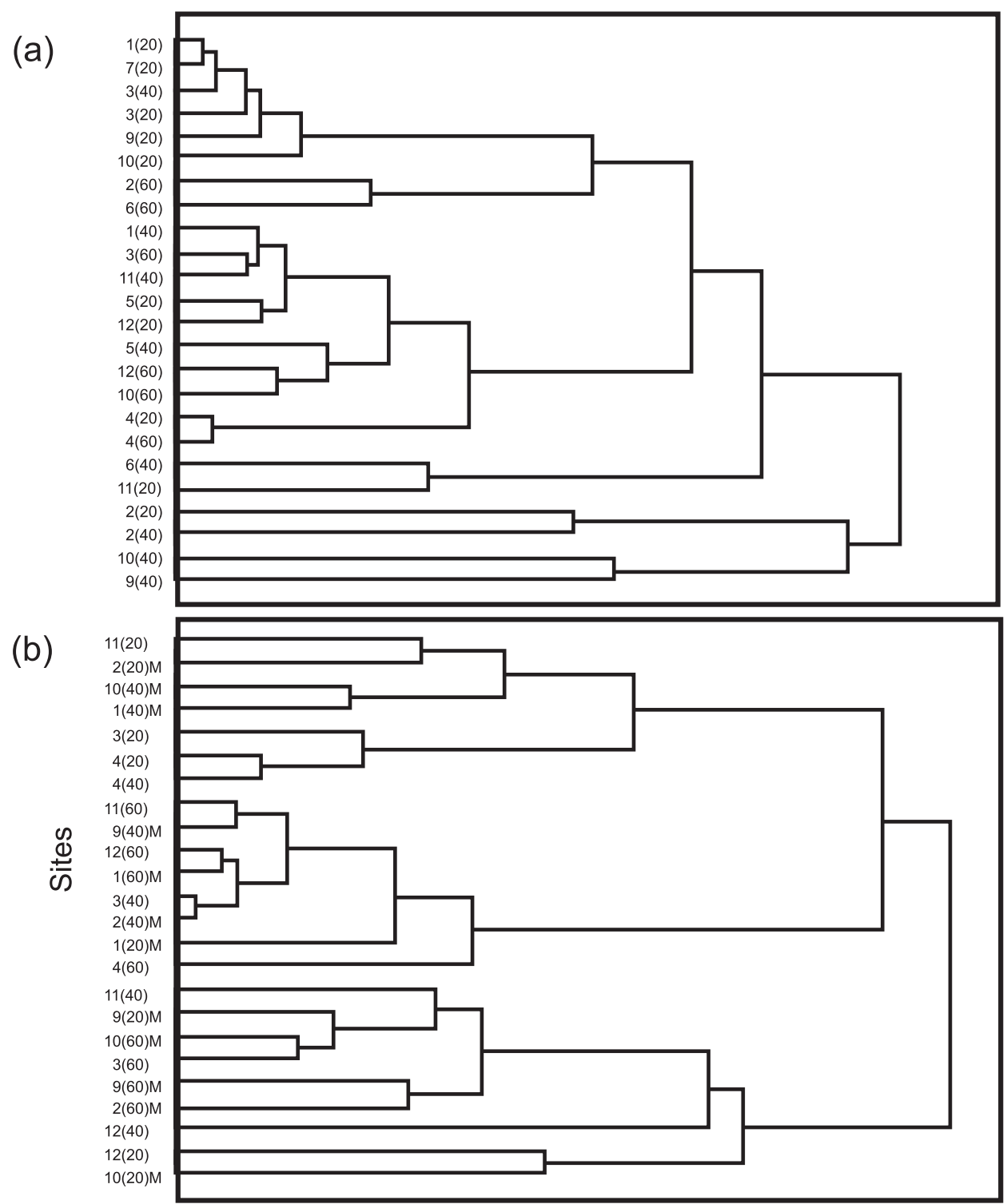

(c)

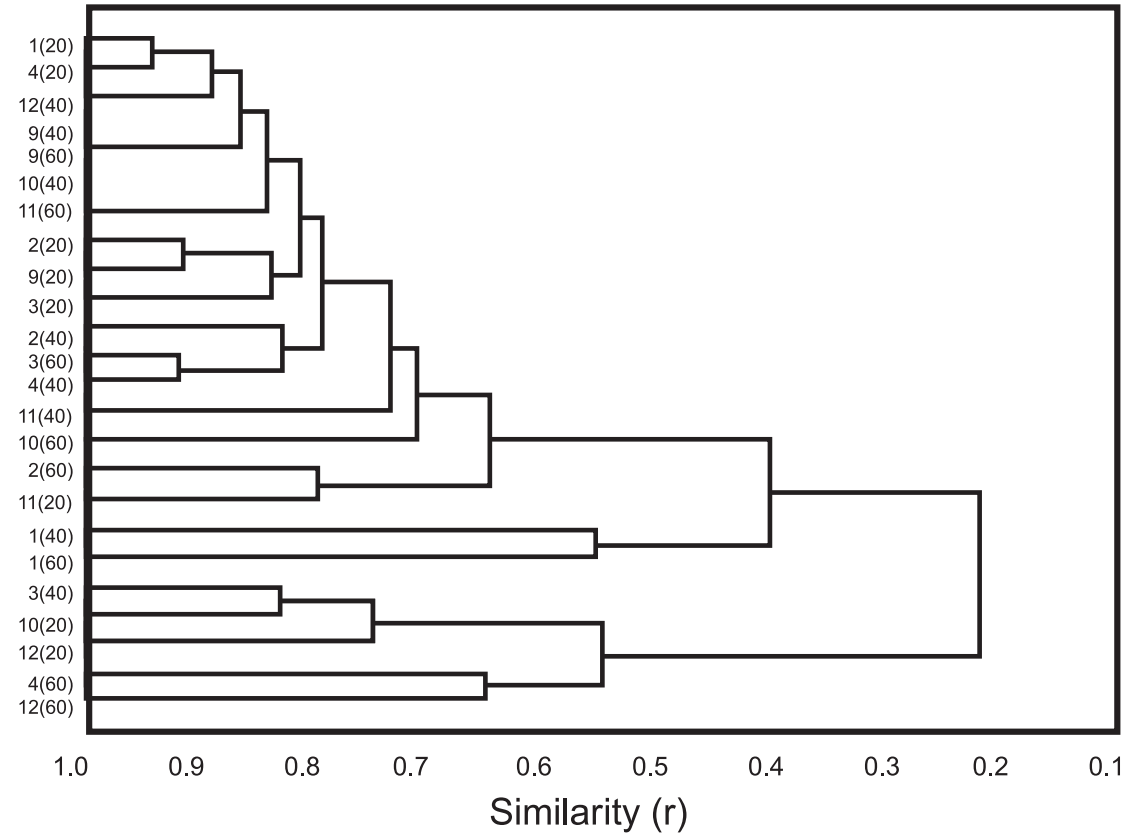


Fig. 3. Unweighted pair group method using arithmetic averages (UPGMA) dendrograms based on comparisons of 16S rDNA (MspI digested) terminal restriction fragment (TRF) patterns during the pre-manipulation $(a)$, manipulation $(b)$, and post-manipulation (c) sampling periods. The $y$ axes correspond to samples taken from various depths on the riffle. Numbers in parentheses denote sampling depth. The $x$ axes represent Pearson's correlation coefficient $(r)$.

Table 4. Eigenvalues and microbial-physicochemical correlation coefficients for correspondence analysis (CA) and canonical correspondence analysis (CCA).

\begin{tabular}{lccccc}
\hline & & & & $\begin{array}{c}\text { Canonical or } \\
\text { unconstrained } \\
\text { eigenvalue }\end{array}$ \\
\hline Before manipulation & Axis 1 & Axis 2 & Axis 3 & Axis 4 & \\
CA eigenvalue & & & & & \\
CCA eigenvalue & 0.311 & 0.269 & 0.212 & 0.187 & \\
Taxon-environment correlation & 0.225 & 0.171 & 0.120 & 0.088 & 0.451 \\
Manipulation & 0.905 & 0.868 & 0.871 & 0.912 & \\
CA eigenvalue & & & & & \\
CCA eigenvalue & 0.509 & 0.459 & 0.182 & 0.130 & \\
Taxon-environment correlation & 0.320 & 0.238 & 0.116 & 0.095 & 0.535 \\
After manipulation & 0.837 & 0.741 & 0.950 & 0.791 & \\
CA eigenvalue & & & & & \\
CCA eigenvalue & 0.249 & 0.098 & 0.067 & 0.042 & \\
Taxon-environment correlation & 0.185 & 0.146 & 0.094 & 0.075 & 0.580 \\
\hline
\end{tabular}

and manipulated areas, $\mathrm{S} 2 \mathrm{M}$ had a higher $\mathrm{pH}$ than $\mathrm{S} 2 \mathrm{C}$, which is indicative of a greater influence on surface water in the manipulation area than in the control area. Although the temperature in the manipulation area was also significantly lower than in the control area of this site, the difference between groundwater and surface water at this time of the year was not large, thus this variable was not a good indicator of altered hyporheic flows.

\section{Microbial assemblages}

The number of different bacterial OTUs generated in this study is likely an underestimation of richness in the hyporheic zone, since the resolution of T-RFLP analysis is often reduced from the species level to that of higher order groups. Further, populations that are not numerically dominant but have a significant functional role are also not represented (Liu et al. 1997). This is because less dominant populations could fall below detection threshold levels of PCR as well as T-RFLP. Less than $50 \%$ of OTUs generated in this study were present in the RDP database after a model digestion was performed with $M s p I$. One problem with attempting to identify bacteria from natural environments with this method is that a significant proportion of sequenced bacteria in the RDP is skewed towards medically important taxa (Marsh et al. 2000). In addition, 16S rRNA genes from phylogenetically related organisms could result in the production of terminal fragments of identical size (Liu et al. 1997). For these reasons, one cannot positively identify phylogenetic groups or species based on the length of terminal fragments alone. The portion of the hyporheic assemblage that could be associated with organisms identified in the RDP database is gram-negative, mainly aerobic, and can be divided into three general groups, Cytophaga, alpha-Proteobacteria, and gamma-Proteobacteria. Since organisms belonging to these groups are highly diverse (Woese 1987), no further conclusion can be drawn about the functional role they might have within the hyporheic environment. Feris et al. (2003) have also used molecular methods (denaturing gradient gel electrophoresis (DGGE), cloning and sequencing, quantitative real time reverse transcriptase PCR (qPCR)) to study microbial assemblages in the hyporheic zone. As in our study, the majority of microbes they identified were gram-negative heterotrophic bacteria. In addition to alpha- and gammaProteobacteria groups, they observed beta-Proteobacteria, Cyanobacteria, and Nitrospina groups. In contrast to our study, they did not observe any microbes that belonged to the Cytophaga group. The lack of OTUs that had RDP phylotype equivalents belonging to the Cytophaga group in the postmanipulation sample set could have been caused either by seasonal differences or by differences between the molecular technique applied to the first two sample sets and that applied to the last sample set. The former is supported by Feris et al. (2003), who observed significant seasonal differences in hyporheic assemblages in a hyporheic zone. They also detected obvious differences among the assemblages in three different streams. Based on the information derived from our data, the next logical step in dissecting the composition of bacterial assemblages and determining its functional characteristics would be to use group-specific primers (e.g., see Richardson et al. 2002). In addition, several different restriction enzymes are usually needed to resolve species that are phylogenetically similar (Marsh et al. 2000). Studies using primers that target functional genes, such as nifH, which is carried by nitrogen-fixing organisms (e.g., Poly et al. 2001), would prove very useful in unravelling the functional roles of hyporheic assemblages.

Cluster analysis performed on the microbial data showed that assemblage composition within the hyporheic sediments 
Fig. 4. Canonical correspondence analysis ordination plots of the pre-manipulation $(a)$, manipulation $(b)$, and post-manipulation $(c)$ microbial assemblages and physicochemical variables. Numbers represent TRF sizes. The broken lines enclose samples from the same depth (not shown for clarity). DO, dissolved oxygen; DOC, dissolved organic carbon; temp, interstitial water temperature; VHG, vertical hydraulic gradient; POM, particulate organic matter; redox, redox potential; depth, depth in the sediment $(20,40$, and $60 \mathrm{~cm})$; $\mathrm{NH}_{4}$, ammonium concentration; $\mathrm{NO}_{3}$, nitrate concentration; $>2 \mathrm{~mm},<600 \mu \mathrm{m}$, and $<250 \mu \mathrm{m}$ are sediment grain sizes.
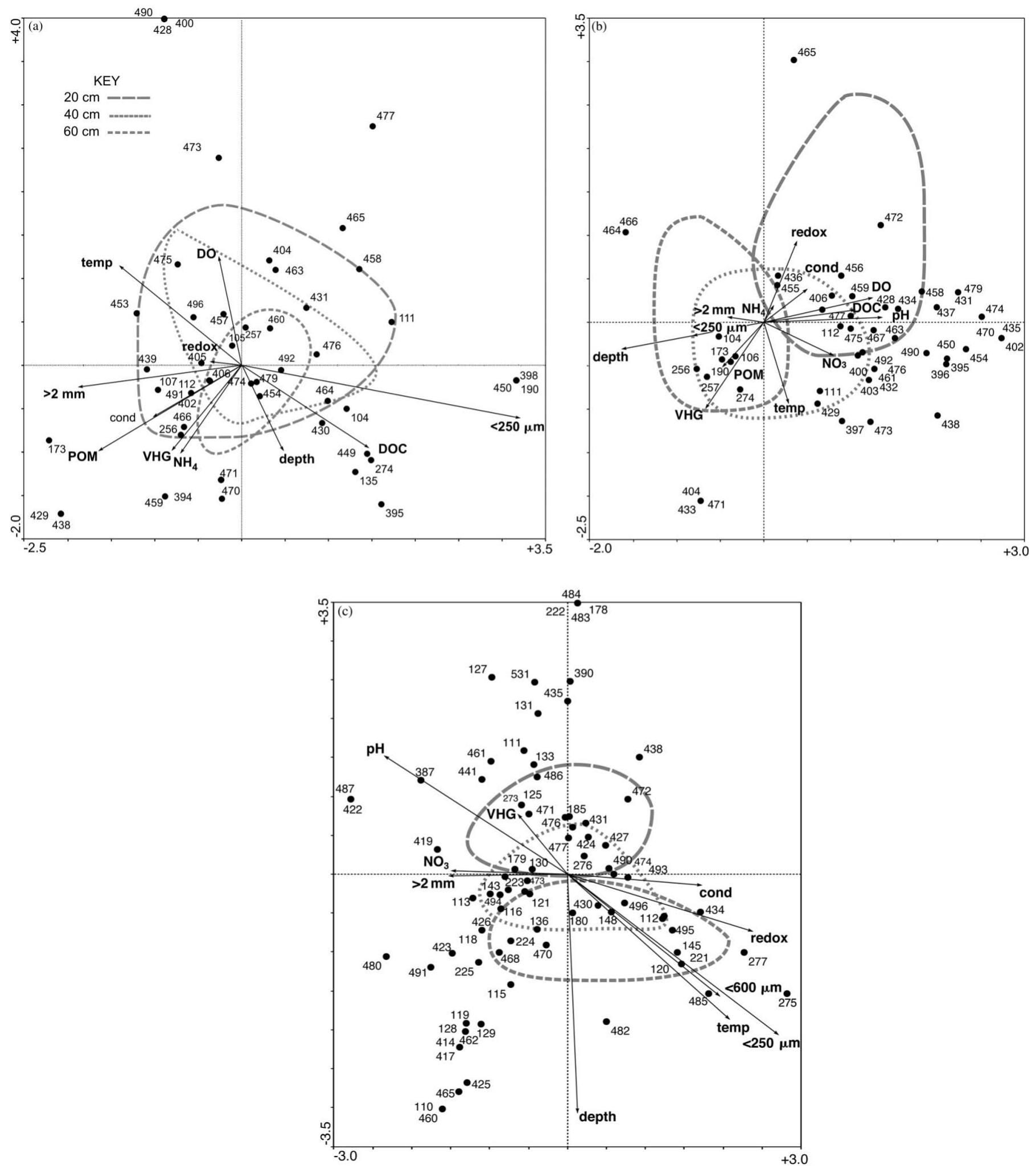
of a single riffle was very heterogeneous and was not structured by the direction of vertical flows in the study riffle. This was tested by comparing areas of naturally contrasting VHG, as well as areas of manipulated vertical flows. This heterogeneity persisted throughout the three sampling periods as well as throughout the flow manipulation. Since the hyporheic environment in this study site is extremely patchy, with some subareas within the downwelling zone exhibiting characteristics of upwelling and vice versa (Storey et al. 1999), the lack of strong grouping among samples derived from similar sites within the riffle is not surprising. These patchy characteristics can be caused by local variations in flow caused by subsurface features such as large buried rocks and clay lenses (Brunke 1999). Feris et al. (2003) have also found microbial assemblages to be highly heterogeneous within a particular stream, although they only sampled upstream riffle locations.

It is possible that microbial assemblages are structured by environmental variation on a smaller scale than was measured here. Soil microbial populations, for example, display nonrandom heterogeneous distribution in soil matrices that result from differences between microenvironments in factors that have been shown to directly affect the survival of bacteria, such as water and nutrient availability (Ranjard and Richaume 2001). Furthermore, most bacteria in sediment habitats are attached to sediment particles to form highly complex biofilm assemblages (Costerton et al. 1995), which allow the microscale coexistence of a variety of bacterial types with contrasting metabolic requirements (Storey et al. 1999). Part of this complexity originates from steep diffusion gradients of nutrients and metabolites, thus spatial heterogeneity may result from differential growth of individual cells or microcolonies under a variety of local environmental conditions (Fenchel 2002).

Unfortunately, problems experienced with molecular techniques that forced a change in methods between sample sets preclude making comparisons among sample sets. It would have been interesting to look at temporal differences or similarities in the microbial assemblages. However, based on the lack of patterns across the spatial scale and the fact that the samples could not be collected from exactly the same locations, similar heterogeneity would have probably been observed over time also. The cluster analysis did, however, show slight grouping of some samples derived from similar depths. This suggests that hyporheic microbial assemblages are more likely to be structured by changes in environmental and (or) biological parameters that vary among depths below streambed rather than by those that vary between horizontal locations within the riffle.

Similar to the results of the cluster analysis, microbial OTU richness did not appear to vary significantly between zones or among depths. The only exception was after the manipulation, when microbial OTU richness was significantly lower in the originally downwelling site than in the upwelling site. The opposite was expected, since the upstream site was more influenced by surface water and thus most likely received a greater diversity and (or) amount of labile food in the form of POM and DOC than the downstream site, which was dominated by groundwater. Groundwater-dominated areas, such as the deeper sediments, have been shown to contain less complex microbial assemblages than near-surface areas (Chandler et al. 1997).

The proportion of OTUs that was unique to a single site or depth was largest in the downwelling zone and at $40 \mathrm{~cm}$ depth before and during the flow manipulation. The larger number of unique OTUs in the downwelling zone versus the upwelling zone may have resulted from the larger diversity of food for hyporheic microbes carried by infiltrating stream water. The larger proportion of OTUs that were unique to an intermediate depth for these two sampling periods may have resulted from a greater mixing of groundwater and surface water at that depth compared with the other depths. Microorganisms are known to concentrate at interfaces, where nutrient and energy levels tend to fluctuate (Ash et al. 2002), and the boundary between hyporheic water and groundwater may be one such region. After the manipulation, the upwelling area had a greater number of OTUs. This followed the trend of microbial richness and once again could not be sufficiently explained, since the opposite was expected. The number of unique OTUs decreased with depth for this sampling period. This may be because the hyporheic zone - groundwater boundary had moved closer to the streambed, which is the general trend during this season (Fraser and Williams 1998).

\section{Influence of physicochemistry in structuring microbial assemblages}

There was a lack of correlation between microbial richness and all the physicochemical and biological parameters. The only exception to this occurred during the flowmanipulation period, when microbial richness was positively correlated with temperature and VHG. This may have been primarily due to the relatively large increase in temperature and VHG caused by the S1 manipulation structure (where the downwelling area was converted to upwelling). The observed effect on the diversity of the microbial assemblage within this manipulated area could have been caused by a significant alteration to temperature, which may have encouraged the growth of taxa that are normally numerically less dominant under natural conditions (e.g., nitrifiers; Storey et al. 1999). These taxa would have been underestimated in the other hyporheic areas sampled at the same time, since the techniques used in this study are subject to biases common to all molecular methods (e.g., DNA extraction and PCR). The degree of change in these parameters, although within normal seasonal and spatial fluctuations, may have been larger than is natural for this time of the year and may have forced a significant change in the microbial assemblage. Additionally, the conversion of an area of streambed from a faster flowing to a slower flowing environment could have had a significant influence on the assemblage structure. However, it is very difficult to devise an insitu method for subsurface flow manipulation that does not affect other parameters in the environment.

The CCA results, although not significant, most likely because of the large number of species included in the analysis, did show some interaction trends between microbial assemblages and environmental variables. Depth did not play an important role before the manipulation because many of the $60 \mathrm{~cm}$ depth samples contained too little DNA 
to be PCR-amplified. However depth did appear to be a gradient with which bacterial assemblages were associated (mostly negatively) during and after the flow manipulation. Sediment size fraction $<250 \mu \mathrm{m}$, with which microbes were mostly negatively associated, appeared to be a structuring variable in both pre- and post-manipulation sample sets. It thus appears that microbial assemblages tended to be more associated with larger sediment fractions and shallower sediments.

The other variables that were correlated with the CCA microbial axes were POM before the manipulation, temperature during all sampling periods, DO during the manipulation, and $\mathrm{pH}$ during and after the manipulation. POM appeared to be a predictor of bacterial abundance in the hyporheic zone, most likely because microbes in hyporheic sediments are primarily associated with organic particles or biofilms that coat inorganic particles (Findlay and Sobczak 2000). However, since bacteria can form a substantial fraction of the organic carbon present (Bostrom 1988), bacteria and sediment organic matter may be autocorrelated to some extent. The relationship between bacteria and POM must therefore be interpreted with caution. The quality of organic matter, a factor not measured here, may have an important effect on hyporheic microorganisms, since compositional differences in source waters can influence bioavailability to sediment bacteria (Findlay and Sobczak 2000). For example, groundwater-derived DOC tends to be less labile than that derived from surface water. This may account for the lack of correlation between DOC and the bacterial assemblage in this study. Temperature tends to be positively correlated with sediment bacterial biomass and abundance (Schallenberg and Kalff 1993). Bacteria may respond to temperature changes only at the assemblage level, with individual species being highly adapted to a specific temperature. In this case, the total bacterial abundance may remain the same, while numbers within various populations change. A negative effect of temperature on bacterial abundance noted in other studies could be due to its collinearity with depth (Schallenberg and Kalff 1993). DO was also a structuring variable, possibly because aerobic metabolic processes are more efficient than anaerobic ones (Storey et al. 1999), which may have caused a numerical, and thus a PCR bias towards aerobic microbes. This is further supported by the groups identified with RDP, as well as the relatively high average OTU richness in the S1 manipulation site, where there was a significant reduction in DO during the flowmanipulation portion of this study. As previously mentioned, $\mathrm{pH}$ is considered to be a predictor of assemblage respiration because it decreases with increasing $\mathrm{CO}_{2}$ (Brunke and Gonser 1997). It was therefore not surprising to see that microbial assemblages were associated with this parameter.

The generally low structuring influence of the measured environmental and biological variables on the microbial assemblages may be an indication that bacterial-assemblage composition was influenced by factors other than those measured in this study. One such factor could be grazing by bacteriovorous protozoans, which have been shown to be an important link in the flow of materials and energy between bacteria and higher trophic levels in other systems (the "microbial loop"; Azam et al. 1983). Heterotrophic flagellates, for example, have been shown to be important grazers on bacteria in the water column (Azam et al. 1983). However, since very little is known about the composition, abundance, and activity of protozoans in the hyporheic zone, one can only speculate as to what kind of a structuring influence this trophic level may have, based on information from other systems. Sleigh et al. (1992) reported that protozoan grazing removed $20 \%$ of bacterial production in an English chalk stream. Bott and Kaplan (1990) showed, through grazing studies at $20{ }^{\circ} \mathrm{C}$, that ciliates and flagellates could consume $80 \%-183 \%$ of estimated annual surface sediment bacterial production in White Clay Creek, Pennsylvania, USA. Another factor that may influence bacterial abundance and assemblage composition is virus-induced mortality. Spatially complex subsurface sediments could represent more of an obstacle to the movement of protozoans than to the diffusion of small viruses (Torsvik et al. 2002). The influence of protozoans and viruses may also depend on the nutrient status of the system studied, and could have significantly different effects on bacterial-assemblage composition. For example, Weinbauer and Peduzzi (1995) predicted that heterotrophic nanoflagellates would be expected to be more important as sources of bacterial mortality in oligotrophic systems, whereas viruses should be more important in nutrient-rich environments. Size-selective grazing by protozoans could influence how biomass is distributed into functional groups, and infection by host-specific viruses could determine how functional groups are divided into species (Torsvik et al. 2002).

In conclusion, despite the fact that the manipulation portion of this study was somewhat compromised, largely as a result of in-situ phenomena, the latter contributed useful and original findings to this exploratory study of hyporheic microbial assemblages. Foremost among these was the observed lack of change induced in bacterial OTU richness over a range of physicochemical conditions during the preand post-manipulation phases, but the positive correlation with water temperature when this single variable was pressed (albeit not by design) during the manipulation. Further, the persistence of microbial-assemblage heterogeneity throughout the three sampling periods and throughout the flow manipulation is significant. The finding that interstitial riverine bacterial assemblages were influenced by sediment depth and particle size underlines the importance of the scale at which such studies should be done.

\section{Acknowledgements}

We thank the MacKenzie family for providing unlimited access to the site. Many people provided valuable help in the field as well as the laboratory: Dr. Richard Storey, Alexandra Felin, Katarina Magnusson, Dr. Wolfgang Staubach, Jos Verhulst, Rhoda Deguzman, Catherine Febria, Dr. Dani Boix-Masafret, Kevin Wilson, Steve DiBiase, and Axel Kussmann. Dr. Roberta Fulthorpe provided advice on PCR amplification protocols. This project was funded by a grant from the Natural Sciences and Engineering Research Council of Canada to D.D. Williams.

\section{References}

Applied Biosystems Inc. 2000. GeneScan ${ }^{\circledR}$. Version 2.1 [computer program]. Applied Biosystems, Fredmont, Calif. 
Ash, C., Hanson, B., and Norman, C. 2002. Earth, air, fire and water. Science (Wash., D.C.), 296: 1055.

Azam, F., Fenchel, T., Field, J.G., Gray, J.S., Mayer-Reil, L.A., and Thingstad, T.F. 1983. The ecological role of water-column microbes in the sea. Mar. Ecol. Progr. Ser. 10: 257-263.

Baxter, C.V., and Hauer, F.R. 2000. Geomorphology, hyporheic exchange, and selection of spawning habitat by bull trout (Salvelinus confluentus). Can. J. Fish. Aquat. Sci. 57: 1470-1481.

Bostrom, B. 1988. Relations between chemistry, microbial biomass and activity in sediments of sewage-polluted vs. non-polluted eutrophic lakes. Verh. Int. Ver. Theor. Angew. Limnol. 23: 451459.

Bott, T.L., and Kaplan, L.A. 1990. Potential for protozoan grazing of bacteria in streambed sediments. J. N. Am. Benthol. Soc. 9: 336-345.

Boulton, A.J., and Foster, J.G. 1998. Effects of buried leaf litter and vertical hydrologic exchange on hyporheic water chemistry and fauna in a gravel-bed river in northern New South Wales, Australia. Freshw. Biol. 40: 229-243.

Boulton, A.J., Findlay, S., Marmonier, P., Stanley, E.H., and Valett, H.M. 1998. The functional significance of the hyporheic zone in streams and rivers. Annu. Rev. Ecol. Syst. 29: 59-81.

Brunke, M. 1999. Colmation and depth filtration within streambeds: retention of particles in hyporheic interstices. Int. Rev. Hydrobiol. 84: 99-117.

Brunke, M., and Gonser, T. 1997. The ecological significance of exchange processes between rivers and groundwater. Freshw. Biol. 37: 1-33.

Centre for Biometry. 1997. Canoco ${ }^{\circledR}$ for Windows. Version 4.0 [computer program]. Centre for Biometry, Wageningen, the Netherlands.

Chandler, D.P., Frederickson, J.K., and Brockman, J. 1997. Effect of PCR template concentration on the composition and distribution of total community $16 \mathrm{~S}$ rDNA clone libraries. Mol. Ecol. 6: 475-482.

Chapman, L.J., and Putnam, D.L. 1966. The physiography of southern Ontario. University of Toronto Press, Toronto, Ont.

Claret, C., Marmonier, P., and Bravard, J. 1998. Seasonal dynamics of nutrient and biofilm in interstitial habitats of two contrasting riffles in regulated large river. Aquat. Sci. 60: 33-55.

Costerton, J.W., Lewandowski, Z., Caldwell, D.E., Korber, D.R., and Lappin-Scott, H.M. 1995. Microbial biofilms. Annu. Rev. Microbiol. 48: 711-745.

Fenchel, T. 2002. Microbial behaviour in a heterogeneous world. Science (Wash., D.C.), 296: 1068-1071.

Feris, K.P., Frazar, C.F., Rilling, M.C., Gannon, J.E., and Holben, W.E. 2003. Structure and seasonal dynamics of hyporheic zone microbial communities in free-stone rivers of the western United States. Microb. Ecol. 46: 200-215.

Findlay, S., and Sobczak, W.V. 1996. Variability in removal of dissolved organic carbon in hyporheic sediments. J. N. Am. Benthol. Soc. 15: 35-41.

Findlay, S.D., and Sobczak, W.D. 2000. Microbial communities in hyporheic sediments. In Streams and ground waters. Edited by J.B. Jones and P.J. Mulholland. Academic Press, San Diego. pp. 287-306.

Franken, R.J.M., Storey, R.G., and Williams, D.D. 2001. Biological, chemical and physical characteristics of downwelling and upwelling zones in the hyporheic zone of a north-temperate stream. Hydrobiologia, 444: 183-195.

Fraser, B.G., and Williams, D.D. 1998. Seasonal boundary dynamics of a groundwater/surface-water ecotone. Ecology, 79: 20192031.
Hendricks, S.P. 1993. Microbial ecology of the hyporheic zone: a perspective integrating hydrology and biology. J. N. Am. Benthol. Soc. 12: 70-78.

Hendricks, S.P. 1996. Bacterial biomass, activity, and production within the hyporheic zone of a north-temperate stream. Arch. Hydrobiol. 136: 467-487.

Henry, J.C., and Fisher, S.G. 2003. Spatial segregation of periphyton communities on a desert stream; causes and consequences of N cycling. J. N. Am. Benthol. Soc. 22: 511-527.

Jongman, R.H.G., ter Braak, C.J.F, and van Tongeren, O.F.R. (Editors). 1995. Data analysis in community and landscape ecology. Cambridge University Press, Cambridge.

Leichtfried, M. 1985. Organic matter in gravel streams (Project Ritrodat-Luntz). Verh. Int. Ver. Theor. Agnew. Limnol. 22: 2058-2062.

Liu, W.T., Marsh, T.L., Cheng, H., and Forney, L.J. 1997. Characterization of microbial diversity by determining terminal restriction fragment length polymorphism of genes encoding $16 \mathrm{~S}$ rRNA. Appl. Environ. Microbiol. 63: 4576-4522.

Marsh, T.L., Saxman, P., Cole, J., and Tiedje, J. 2000. Terminal restriction fragment length polymorphism analysis program, a web-based research tool for microbial community analysis. Appl. Environ. Microbiol. 66: 3616-3620.

Nelson, D.W., and Sommers, L.E. 1996. Total carbon, organic carbon and organic matter. In Methods of soil analysis. Part 3. Chemical methods. Edited by D.L. Sparks. Soil Science Society of America and American Society of Agronomy, Madison, Wis. pp. 961-1010.

Osborn, A.M., Moore, E.R., and Timmins, K.N. 2000. An evaluation of terminal-restriction fragment length polymorphism (TRFLP) analysis for the study of microbial community structure and dynamics. Environ. Microbiol. 2: 39-50.

Palmer, M.W. 1993. Putting things in even better order: the advantages of canonical correspondence analysis. Ecology, 74: 22152230.

Poly, F., Ranjard, L., Nazaret, S., Gourbiere, F., and Jocteur Montrozier, L. 2001. Comparison of nif $\mathrm{H}$ gene pools between soils and soil microenvironments of contrasting properties. Appl. Environ. Microbiol. 67: 2255-2262.

Ranjard, L., and Richaume, A. 2001. Quantitative and qualitative microscale distribution of bacteria in soil. Res. Microbiol. 152: 707-716.

Richards, C., and Bacon, K.L. 1994. Influence of fine sediment on macroinvertebrate colonisation of surface and hyporheic stream sediments. Gt. Basin Nat. 54: 106-113.

Richardson, R.E., Bhupathiraju, V.K., Song, D.L., Goulet, T.A., and Alvarez-Cohen, L.A. 2002. Phylogenetic characterization of microbial communities that reductively dechlorinate TCE based upon a combination of molecular techniques. Environ. Sci. Tech. 36: 2652-2662.

SAS Institute Inc. 1999. StatView ${ }^{\circledR}$ for Windows. Version 5.0 [computer program]. SAS Institute Inc., Cary, N.C.

Schallenberg, M., and Kalff, J. 1993. The ecology of sediment bacteria in lakes and comparisons with other aquatic ecosystems. Ecology, 74: 919-934.

Sleigh, M.A., Baldock, B.M., and Baker, J.H. 1992. Protozoan communities in chalk streams. Hydrobiologia, 248: 53-64.

Storey, R.G., Fulthorpe, R.R., and Williams, D.D. 1999. Perspectives and predictions on the microbial ecology of the hyporheic zone. Freshw. Biol. 41: 119-130.

Storey, R.G., Howard, K.W.F., and Williams, D.D. 2003. Factors controlling riffle-scale hyporheic exchange flows and their seasonal changes in an effluent stream: a three-dimensional groundwater flow model. Water Resour. Res. 39: 1-17. 
Torsvik, V., Ovreas, L., and Thingstad, T.F. 2002. Prokaryotic diversity - magnitude, dynamics and controlling factors. Science (Wash., D.C.), 296: 1064-1066.

Weinbauer, M.G., and Peduzzi, P. 1995. Significance of viruses versus heterotrophic nanoflagellates for controlling bacterial abundance in the northern Adriatic Sea. J. Plankton Res. 17: 1851-1856.

Williams, D.D. 1984. The hyporheic zone as a habitat for aquatic insects and associated arthropods. In The ecology of aquatic insects. Edited by V.H. Resh and D.M. Rosenberg. Praeger, New York. pp. 430-455.
Williams, D.D., and Hynes, H.B.N. 1974. The occurrence of benthos in the deep substratum of a stream. Freshw. Biol. 4: 233-256.

Williams, D.D., and Hynes, H.B.N. 1976. The recolonisation mechanisms of stream benthos. Oikos, 27: 265-272.

Woese, C.R. 1987. Bacterial evolution. Microbiol. Rev. 51: 221271.

Zhou, J., Bruns, M.A., and Tiedje, J.M. 1996. DNA recovery from soils of diverse composition. Appl. Environ. Microbiol. 62: 316322. 